\title{
PELAKSANAAN DIET DAN STATUS GIZI SERTA KEMANDIRIAN PENDERITA HIPERTENSI LANSIA DI DESA BONTO MARANNU
}

\author{
Hendrayati ${ }^{1}$, Putri Indah Nirmalasari ${ }^{2}$ \\ ${ }^{1}$.Jurusan Gizi Poltekkes Kemenkes Makassar \\ ${ }^{2}$ Petugas Gizi, RS. Ibnu Sina, Makassar
}

Korespondensi : hendragizi@yahoo.co.id

\begin{abstract}
Increased Life Expectancy (UHH) in Indonesia is a success in the field of health and welfare. UHH can increase the elderly population (elderly) by decreasing mortality. The 2015 Central Bureau of Statistics (BPS) report, UHH in 2015 became 70.8 years and will increase to 72.2 years in 2030-2035, while in Maros district in 2015 for UHH increased to 68.55 years. The aging process in the elderly has the risk of non-communicable diseases, such as hypertension. The results of the Basic Health Research (Riskesdas) in 2013, showed that the health problems in the highest elderly were Hypertension with the category age of 55-64 years of $45.9 \%, 65-74$ years of $57.6 \%$ and 75 years and over $63.8 \%$. Hypertension in the elderly can affect the level of dependence on the surrounding environment. The dependency ratio of Indonesia's elderly population in 2016 was $13.65 \%$. This means that every 100 people of productive age must bear about 14 elderly residents. The dependency ratio in South Sulawesi is $14.62 \%$, which means that every 100 productive residents in South Sulawesi must bear around 15 elderly residents. This study is an analytical study with a cross sectional study design. The population in this study were all elderly aged 60-80 years. Sampling using purposive sampling with sample criteria as follows: 60 - 80 years old, have a history of hypertension and / or have high blood pressure $(\geq 140 / 90 \mathrm{mmHg})$ at the time of measurement, Willing to be interviewed, Not having hearing and memory disorders (senile) and can be invited to communicate clearly. Samples that fit the criteria in this study were 47 people. Research result is a disobedience to the hypertension diet in elderly people with very high hypertension reaches $91.5 \%$, and insignificant relationship between nutritional status and the independence of the elderly both the age group $<75$ years and the age group $\geq 75$ years with a significant value of each $p=0.619$ and $p=0.191$. There is a nonsignificant relationship between hypertension and the independence of the elderly both in the age group $<75$ years and the age group $\geq 75$ years with a significant value of $p=0.447$ and $p=0.362$. The elderly with hypertension sufferers should always be given counseling and / or nutritional consultation to increase their understanding of the diet being undertaken
\end{abstract}

\section{PENDAHULUAN}

Peningkatan Usia Harapan Hidup (

UHH) di Indonesia merupakan keberhasilan dalam bidang kesehatan dan kesejahteraan. UHH dapat meningkatkan populasi lanjut usia (lansia) dengan menurunnya angka kematian. Laporan Badan Pusat Statistik (BPS) tahun 2015, UHH pada tahun 2015 menjadi 70,8 tahun dan akan meningkat menjadi 72,2 tahun 
pada tahun 2030-2035, sedangkan di kabupaten Maros pada tahun 2015 untuk UHH meningkat menjadi 68,55 tahun (Pusdatin Kemenkes RI, 2013).

Pada tahun 2000, penduduk lansia berjumlah 14,45 juta jiwa atau $7,18 \%$ dari seluruh penduduk Indonesia. Jumlah tersebut meningkat menjadi 18,04 juta jiwa (7,56\%) pada tahun 2010. Badan Pusat Statistik memproyeksikan jumlah penduduk lansia pada tahun 2020 sebanyak 27,09 juta jiwa atau 9,99\% dari jumlah penduduk Indonesia dan pada tahun 2035 diprediksi melonjak menjadi 48,20 juta jiwa atau $15,77 \%$ dari seluruh penduduk (BPS, 2016).

Peningkatan penduduk lansia ini berakibat pada timbulnya masalah gizi dan kesehatan seperti gizi kurang, gizi lebih dan beberapa penyakit degeneratif, sehingga lansia merupakan golongan yang rawan mengalami masalah gizi. Masalah gizi pada lansia dapat mempengaruhi kualitas hidup lansia. Salah satu masalah yang timbul pada lansia adalah rendahnya asupan dan cenderung menurun mulai dari usia 70 tahun. Sebagian besar orang berusia di atas 70 tahun cenderung mengalami penurunan berat badan. Rendahnya asupan berdampak pada status gizi. Hasil penelitian Nurhalimah (2016) menunjukkan bahwa status gizi pada lansia sebanyak $36,4 \%$ tidak normal. Nurhalimah, 2016).

Proses penuaan pada lansia memiliki resiko terjadinya penyakit tidak menular, misalnya hipertensi. Hasil Riset Kesehatan Dasar (Riskesdas) tahun 2013, menunjukan masalah kesehatan pada lansia paling tinggi adalah Hipertensi dengan kategori umur 55-64 tahun sebesar 45,9\%, 65-74 tahun sebesar 57,6\% dan 75 tahun ke atas sebesar 63,8\% (Pusdatin Kemenkes RI, 2016). Hipertensi pada lansia dapat mempengaruhi tingkat ketergantungan pada lingkungan sekitar. Rasio ketergantungan penduduk lansia Indonesia pada tahun 2016 sebesar 13,65\%. Artinya bahwa setiap 100 orang penduduk usia produktif harus menanggung sekitar 14 orang penduduk lansia. Rasio ketergantungan di Sulawesi Selatan sebesar $14,62 \%$ yang artinya setiap 100 penduduk produktif di Sulawesi Selatan harus menanggung sekitar 15 orang penduduk lansia (BPS, 2016).

Hasil penelitian Fajar (2016) menyatakan bahwa ketidakmampuan lansia dalam melakukan aktivitas sehari-hari merupakan salah satu faktor risiko timbulnya masalah gizi. Timbulnya masalah gizi disebabkan oleh rendahnya pengetahuan dan pemahaman lansia tentang gizi dan penyelenggaraan diet, dalam hal ini diet ketika mengalami hipertensi (Fajar,2016). Hasil penelitian Putri 2018 di Desa Bonto Marannu Maros menujunkan bahwa ada hubungan kejadian hipertensi dan ketergantungan, status gizi dan aktifitas fisik pada lansia. Pada penelitian lanjutan yang dilakukan di tempat yang sama untuk mengukur pengetahuan dan pelaksanaan tatalaksana makan pada lansia penderita hipertensi.

\section{METODE}

Penelitian ini merupakan penelitian analitik dengan desain cross sectional study. Penelitian ini dilakukan di Desa Bonto Marannu, Kecamatan Moncongloe, Kabupaten Maros, Sulawesi Selatan. Lokasi penelitian ini ditentukan secara purposive dengan pertimbangan bahwa angka lansia hipertensi cukup tinggi di desa ini dibandingkan dengan desa-desa yang lain di Kecamatan Moncongloe. Penelitian ini dilaksanakan pada bulan Mei - Desember 2018. Populasi dalam penelitian ini adalah semua lansia di Desa Bonto Marannu yang berusia 60 - 80 tahun. Penarikan sampel menggunakan purposive sampling dengan kriteria sampel sebagai berikut : Berusia $60-80$ tahun, Mempunyai riwayat hipertensi dan atau mempunyai tekanan darah tinggi $(\geq 140 / 90$ $\mathrm{mmHg}$ ) pada saat pengukuran, Bersedia 
diwawancarai, Tidak memiliki gangguan pendengaran dan ingatan (pikun) dan dapat diajak berkomunikasi dengan jelas. Sampel yang sesuai dengan kriteria pada penelitian ini sebanyak 47 orang.

Instrumen yang digunakan adalah kuesioner yang pelaksanaan pengisiannya menggunakan pemandu atau pendamping yang dapat memberikan informasi pada peneliti atas apa yang disampakan oleh responden. Pelaksanaan diet digunakan formulir cek lis tentang pelaksanaan diet yang diukur dari jenis menu yang disampaikan maupun yang dilihat langsung pada saat penelitian. Data status gizi diperoleh dengan menggunakan Indeks Masa Tubuh (IMT) dari data berat badan yang diperoleh dari hasil pengukuran menggunakan timbangan digital. Data tinggi badan diperoleh dengan cara konversi dari tinggi lutut menggunakan meteran. Hasil IMT kemudian dibandingkan dengan kriteria objektif untuk melihat kategori status gizi.

\section{HASIL}

Jumlah keseluruhan responden pada penelitian ini adalah 47 responden berusia 60 - 80 tahun yang dikelompokkan menjadi 2 (dua) kelompok. Tabel 01 memaparkan distribusi usia responden dapat dilihat pada tabel 01.

Tabel 1

Kelompok Usia Responden di Desa Bonto Marannu

\begin{tabular}{ccc}
\hline $\begin{array}{c}\text { Kelompok } \\
\text { Usia }\end{array}$ & $\begin{array}{c}\text { Jumlah } \\
\text { (n) }\end{array}$ & $\begin{array}{c}\text { Persentase } \\
(\mathbf{\%})\end{array}$ \\
\hline$<75$ tahun & 30 & 64 \\
$\geq 75$ tahun & 17 & 36 \\
Total & $\mathbf{4 7}$ & $\mathbf{1 0 0}$ \\
\hline
\end{tabular}

Dari Tabel 01, terlihat bahwa kelompok usia $<75$ tahun sebanyak 30 responden $(64 \%)$ dan kelompok usia $\geq 75$ tahun sebanyak 17 responden
(36\%). Usia termuda pada penelitian ini 60 tahun dan usia tertua 74 tahun.

Hasil pengukuran kriteria hipertensi yang dilakukan berulang kali menunjukan hasil pada tabel 02 .

Tabel 2

Distribusi Frekuensi Penyakit

Hipertensi Responden

di Desa Bonto Marannu

\begin{tabular}{ccccc}
\hline $\begin{array}{c}\text { Penyakit } \\
\text { Hipertensi } \\
\text { Responden }\end{array}$ & \multicolumn{2}{c}{$\begin{array}{c}\text { Usia } \\
\mathbf{2 7 5}\end{array}$} & \multicolumn{2}{c}{$\begin{array}{c}\text { Usia } \\
\text { tahun } \\
\text { tahun }\end{array}$} \\
\cline { 2 - 5 } & $\mathbf{n}$ & $\mathbf{\%}$ & $\mathbf{n}$ & $\mathbf{\%}$ \\
\hline Hipertensi Stage II & 12 & 40 & 2 & 12 \\
Hipertensi Stage I & 18 & 60 & 15 & 88 \\
Total & $\mathbf{3 0}$ & $\mathbf{1 0 0}$ & $\mathbf{1 7}$ & $\mathbf{1 0 0}$ \\
\hline
\end{tabular}

Dari Tabel 02, diketahui bahwa pada umumnya klasifikasi penyakit hipertensi responden paling banyak berada pada stage I. Rata masa menderita hipertensi diatas 5 tahun.

Tabel 3

Distribusi Frekuensi Pekerjaan

Responden di Desa Bonto Marannu

\begin{tabular}{lcccc}
\hline $\begin{array}{c}\text { Pekerjaan } \\
\text { Responden }\end{array}$ & $\begin{array}{c}\text { Usia } \\
<75\end{array}$ & \multicolumn{2}{c}{$\begin{array}{c}\text { Usia } \\
\mathbf{2 7 5} \\
\text { tahun }\end{array}$} & \multicolumn{2}{c}{ tahun } \\
\cline { 2 - 5 } & $\mathbf{n}$ & $\mathbf{\%}$ & $\mathbf{n}$ & $\mathbf{\%}$ \\
\hline Bekerja & 1 & 3 & 0 & 0 \\
Tidak Bekerja & 27 & 90 & 17 & 100 \\
Pensiunan & 2 & 7 & 0 & 0 \\
Total & $\mathbf{3 0}$ & $\mathbf{1 0 0}$ & $\mathbf{1 7}$ & $\mathbf{1 0 0}$ \\
\hline
\end{tabular}

Dari Tabel 03, diketahui bahwa saat ini sebagian besar responden sudah tidak bekerja dengan rutin, atau tidak melaksanakan aktifitas yang menghasilkan uang. 
Tabel 4

Distribusi Frekuensi Status Gizi

Responden di Desa Bonto Marannu

\begin{tabular}{ccccc}
\hline \multirow{2}{*}{$\begin{array}{c}\text { Status Gizi } \\
\text { Responden }\end{array}$} & \multicolumn{2}{c}{$\begin{array}{c}\text { Usia } \\
<\mathbf{7 5} \\
\text { tahun }\end{array}$} & \multicolumn{2}{c}{$\begin{array}{c}\text { Usia } \\
\mathbf{2 7 5} \\
\text { tahun }\end{array}$} \\
\cline { 2 - 6 } & $\mathbf{n}$ & $\mathbf{\%}$ & $\mathbf{n}$ & $\mathbf{\%}$ \\
\hline Tidak & 16 & 53 & 6 & 35 \\
Normal & & & & \\
Normal & 14 & 47 & 11 & 65 \\
Total & $\mathbf{3 0}$ & $\mathbf{1 0 0}$ & $\mathbf{1 7}$ & $\mathbf{1 0 0}$ \\
\hline
\end{tabular}

Dari Tabel 04, diketahui bahwa pada umumnya status gizi responden usia $<75$ tahun sebanyak 16 responden berstatus gizi tidak normal (53\%) dan pada umumnya status gizi responden usia $\geq 75$ tahun sebanyak 11 responden berstatus gizi normal $(65 \%)$. Status gizi tidak normal merupakan gabungan dari kurang dan lebih.

Tabel 5

Distribusi Frekuensi Pelaksanaan Diet Hipertensi di Desa Bonto Marannu

\begin{tabular}{lcccc}
\hline \multirow{2}{*}{ Pelaksanaan Diet } & \multicolumn{2}{c}{ Ya } & \multicolumn{2}{c}{ Tidak } \\
\cline { 2 - 5 } & $\mathbf{n}$ & $\boldsymbol{\%}$ & $\mathbf{n}$ & $\boldsymbol{\%}$ \\
\hline Diet secara mandiri & 28 & 59.59 & 19 & 40.41 \\
\hline Mempertahankan diet & 4 & 8.5 & 43 & 91.5 \\
\hline
\end{tabular}

Dari Tabel 05, menunjukan pelaksanaan diet hipertensi yang dilakukan oleh responden berdasarikan saran dari petugas gizi yang dilaksanakan pada saat konsultasi di posyandu lansia. Sebanyak
$59.59 \%$ responden melaksanakan diet secara mandiri dan $91.5 \%$ responden tidak dapat mempertahankan diet yang harus dijalani.

Tabel 6

Distribusi Frekuensi Kemandirian Responden di Desa Bonto Marannu

\begin{tabular}{ccccc}
\hline \multirow{2}{*}{$\begin{array}{c}\text { Kemandirian } \\
\text { Responden }\end{array}$} & \multicolumn{2}{c}{ Usia $<\mathbf{7 5}$ tahun } & \multicolumn{2}{c}{ Usia $\geq \mathbf{7 5}$ tahun } \\
\cline { 2 - 5 } & $\mathbf{n}$ & $\mathbf{\%}$ & $\mathbf{n}$ & $\mathbf{\%}$ \\
\hline Tidak Mandiri & 10 & 33 & 12 & 71 \\
Mandiri & 20 & 67 & 5 & 29 \\
Total & $\mathbf{3 0}$ & $\mathbf{1 0 0}$ & $\mathbf{1 7}$ & $\mathbf{1 0 0}$ \\
\hline
\end{tabular}

Dari Tabel 06, diketahui bahwa pada umumnya pada umumnya kemandirian responden usia $<75$ tahun sebanyak 20 responden adalah mandiri $(67 \%)$ dan pada umumnya kemandirian responden usia $\geq 75$ tahun sebanyak 12 responden adalah tidak mandiri $(71 \%)$. 
Tabel 7

Analisis Data Hubungan Antar Variabel Kelompok

Usia $<75$ tahun di Desa Bonto Marannu, Kecamatan

Moncongloe, Kabupaten Maros, Tahun 2018

\begin{tabular}{clcc}
\hline No. & Variabel Penelitian & $\begin{array}{c}\text { Nilai } \\
\text { Korelasi }\end{array}$ & $\begin{array}{c}\text { Nilai } \\
\text { Signifikan (2- } \\
\text { tailed) }\end{array}$ \\
\hline 1. & $\begin{array}{l}\text { Status Gizi dengan } \\
\text { Kemandirian Lansia }\end{array}$ & 0,094 & 0,619 \\
\hline 2. & $\begin{array}{l}\text { Penyakit Hipertensi dengan } \\
\text { Kemandirian Lansia }\end{array}$ & 0,144 & 0,447 \\
\hline
\end{tabular}

Dari Tabel 07, diketahui bahwa dua dari ketiga variabel dependen dengan variabel independen berhubungan tetapi tidak signifikan karena nilai signifikannya lebih besar dari 0,05 yaitu masing-masing hubungan status gizi dengan kemandirian lansia sebesar 0,619 dan hubungan penyakit hipertensi dengan kemandirian lansia sebesar 0,447, sedangkan untuk hubungan aktivitas fisik dengan kemandirian lansia terdapat hubungan yang bermakna dengan nilai signifikannya yaitu 0,014 .

\section{PEMBAHASAN}

Pada penelitian ini pengukuran hipertensi dilakukan oleh bidan desa Bonto Marannu untuk memperoleh data lansia hipertensi. Kategori penyakit hipertensi sesuai dengan JNC (2003) yaitu hipertensi stage I (140-159 / 90-99 mmHg) dan hipertensi stage II (>160/>100 mmHg). Tabel 02 menunjukkan bahwa kelompok usia <75 tahun dan kelompok usia $\geq 75$ tahun berada pada kategori hipertensi stage I yaitu masing-masing sebanyak 18 responden $(60 \%)$ dan 15 responden $(88 \%)$. Hal ini menunjukan bahwa tingkat penyakit hipertensi yang masih ringan. Meskipun berada pada stage 1 responden memerlukan diet mengingat riwayat penyakit ini sudah diderita rata-rata diatas 5 tahun.
Responden yang mengalami hipertensi disebabkan oleh pola makan yang kurang tepat selain faktor usia. Upaya dari pihak puskesmas sudah dilaksanakan berupa edukasi gizi setiap pelaksanaan posyandu lansia, tidak semua responden melaksanakn diet yang dianjurkan terbukti dengan masih tingginya responden yang tidak melaksanakan diet yang adekuat sebesar $91.5 \%$.

Proses penuaan berbeda untuk setiap individu karena dipengaruhi oleh faktor internal dan eksternal. Asupan gizi dari makanan mempengaruhi proses menjadi tua karena seluruh aktivitas sel memerlukan zat gizi yang cukup selain faktor penyakit dan lingkungan Asupan yang tidak adekuat baik kekurangan maupun berlebih akan membentuk status gizi pada seseorang termasuk lansia (Fatmah, 2010). Penggunaan antropometri dalam menentukan status gizi lansia bukan merupakan indikator satu- satunya, karena nilai antropometri saja menjadi tidak sensitif dan tidak tepat karena seluruh aspek fisik lansia ikut melemah karena usia (Arisman, 2009). Penelitian ini dalam penentuan status gizi lansia tetap menggunakan Indeks Massa Tubuh (IMT) dengan menggunakan tinggi badan estimasi dari koreksi tinggi lutut. Penentuan status gizi berdasarkan IMT dikategorikan menjadi 2 (dua) kategori 
yaitu status gizi tidak normal (malnutrisi dengan interpretasi gizi sangat kurang, gizi kurang, overweight dan obesitas) dengan nilai IMT $<17,0-18,5$ atau $>25,0 \mathrm{~kg} / \mathrm{m}^{2}$ dan status gizi normal dengan nilai IMT $>18,5-25,0 \mathrm{~kg} / \mathrm{m}^{2}$ sesuai rujukan Depkes RI

Tabel 04 menunjukkan bahwa status gizi kelompok usia $\geq 75$ tahun sebagian besar berstatus gizi normal yaitu 11 responden $(65 \%)$, sedangkan kelompok usia $<75$ tahun menunjukkan status gizi yang berbeda yaitu sebanyak 16 responden $(53 \%)$ berstatus gizi tidak normal (malnutrisi). Hal ini sejalan dengan penelitian dari Nurhalimah FR (2016) yang menunjukkan hasil status gizi pada sebagian besar sampel penelitian $(63,6 \%)$ dan penelitian dari Sirait FRH (2015) dengan status gizi normal pada sebagian besar lansia (67,1\%). Mengacu pada penyebab langsung terjadinya malnutrisi, status gizi kurang dan sangat kurang dapat disebabkan oleh asupan makan lansia yang kurang akibat kemunduran organ pencernaan. Begitu pun sebaliknya, lansia yang memiliki status gizi lebih dan gemuk dapat disebabkan oleh mengonsumsi makanan yang berlebih dan kurangnya melakukan aktivitas fisik, selain itu pola makan yang tidak benar misalnya pemilihan makanan yang tinggi kalori dan lemak sebagai dampak dari rendahnya pengetahuan gizi pada lansia. Pada responden status gizi juga banyak dipengaruhi oleh pelaksanaan diet yang dijalani, dimana $91.5 \%$ responden tidak taat terhadap diet yang dijalani

Kemandiarian lansia pada penelitian ini diukur dengan kemampuan aktivitas sehari-hari dengan menggunakan alat atau instrumen yaitu Instrumental Activity Daily lLiving (IADL). Kategori tingkat kemandirian lansia pada penelitian ini menggunakan instrumen rujukan Katz et al. (1970) dan Lawton MP (1971), terdiri atas 2 (dua) kategori yaitu mandiri dan tidak mandiri dengan interpretasi ketergantungan ringan, ketergantungan sebagian dan ketergantungan total (skoring <22) dan mandiri (skoring $22-28$ ).

Tabel 06 menunjukkan bahwa kelompok usia $<75$ tahun berada pada kategori mandiri yaitu sebanyak 20 responden (67\%). Sedangkan untuk kelompok usia $\geq 75$ tahun menunjukkan hasil berbeda yaitu 12 lansia tidak mandiri (71\%). Hal ini menjelaskan bahwa semakin bertambah usia maka lansia juga semakin tidak mandiri yang dapat disebabkan karena usia bertambah maka kemunduran fisik dan status fungsional sehingga dapat menyebabkan ketergantungan (tidak mandiri). Hal ini sejalan dengan data BPS (2016) bahwa rasio ketergantungan penduduk lansia di Sulawesi Selatan sebesar $14,62 \%$ artinya setiap 100 orang penduduk produktif menanggung sekitar 15 orang penduduk lansia.

Berdasarkan hasil uji korelasi Rank Spearman, terdapat hubungan yang tidak signifikan antara status gizi dengan kemandirian lansia (kelompok usia <75 tahun yaitu $\mathrm{p}=0,619$ dan nilai $\mathrm{r}=0,094$ serta kelompok usia $\geq 75$ tahun yaitu $\mathrm{p}=0,191$ dan nilai $r=0,334)$. Pada kelompok usia $<75$ tahun berkorelasi positif yang artinya semakin baik status gizi lansia maka semakin baik pula kemandiriannya, sedangkan pada kelompok usia $\geq 75$ tahun kedua variabel berkorelasi negatif yang artinya semakin baik status gizi lansia maka belum tentu kemandiriannya semakin baik. Hal ini tidak sejalan dengan penelitian Sirait FRH (2015) dan Alfyanita, dkk (2016) yang menyatakan ada hubungan yang bermakna antara kemandirian dan status gizi dengan nilai signifikan masing-masing yaitu $p=0,039$ dan $p=0,015$. Hal ini diduga karena hampir keseluruhan responden berada dalam kondisi mandiri, baik yang mempunyai status gizi normal maupun malnutrisi. Mandiri artinya responden mampu melakukan aktivitas sehari-hari untuk 
memenuhi kebutuhan hidupnya. Kemandirian erat kaitannya dengan mobilitas dan kondisi fisik, dimana mobilitas dan penurunan fisik secara signifkan berhubungan dengan asupan makanan yang buruk dan anoreksia (Abdelrahman and Elawam 2012). Akan tetapi, penelitian ini sejalan dengan penelitian Fajar (2016) yang menyatakan tidak ada hubungan bermakna antara status gizi dengan kemandirian lansia $(p=0,209)$.

Hubungan antara penyakit hipertensi dengan kemandirian lansia dianalisis menggunakan uji korelasi Spearman. Hasil dari penelitian ini didapatkan data bahwa nilai signifikansi untuk kelompok usia $<75$ tahun yaitu $\mathrm{p}=0,447$ dan $\mathrm{r}=0,144$ yang menunjukkan ada hubungan yang tidak signifikan antara aktivitas fisik dengan kemandirian lansia, begitu pula dengan kelompok usia $\geq 75$ tahun yaitu $\mathrm{p}=0,326$ dan $\mathrm{r}=0,236$. Hal ini dapat disebabkan oleh responden mempunyai aktifitas fisik yang baik sehingga menyebabkan penyakit hipertensi yang diderita pada umumnya masih dalam kategori ringan, sehingga penyakit hipertensi ini tidak menjadi penyebab responden untuk tidak mandiri.

Hubungan yang tidak signifikan ini dapat disebabkan oleh banyak faktor. Salah satu faktor yang memengaruhinya adalah kondisi sosial ekonomi. Hasil observasi bahwa lansia yang merasakan sakit masih harus tetap aktif beraktivitas dan mandiri melakukan pekerjaannya disebabkan adanya desakan ekonomi. Menurut Paul et al. (2012), tingkat pendapatan dan pendidikan akan berkontribusi terhadap proses penuaan. Selain itu, jenis penyakit hipertensi yang diderita responden selama merupakan penyakit kronik yang sering kambuh tetapi dapat disembuhkan secara cepat. Hal tersebut tidak terlalu mengganggu contoh dalam melakukan aktivitas sehari-hari secara mandiri. Penelitian ini tidak selaras dengan penelitian Fajar (2016) tentang ada hubungan status kesehatan (keluhan penyakit hipertensi yang diderita responden) dengan kemandiriannya $(\mathrm{p}<0,05)$. Disamping itu, hal ini juga tidak selaras dengan penelitian Sirait FRH (2015) mengenai ada hubungan yang bermakna antara penyakit hipertensi dengan kemandirian lansia $(\mathrm{p}=0,002)$.

\section{KESIMPULAN}

1. Klasifikasi penyakit hipertensi lansia untuk kelompok usia <75 tahun dan kelompok usia $\geq 75$ tahun pada umumnya tergolong hipertensi stage I (60\% dan 88\%)

2. Ketidak patuhan terhadap diet hipertensi pada lansia penderita hipertensi sangat tinggi mencapai 91,5 $\%$

3. Status gizi kelompok usia $<75$ tahun pada umumnya tergolong normal (53\%) sedangkan untuk kelompok usia $\geq 75$ tahun pada umumnya tergolong tidak normal $(65 \%)$

4. Kemandirian lansia kelompok usia $<75$ tahun dan pada umumnya tergolong mandiri (67\%), sedangkan kelompok usia $\geq 75$ tahun pada umumnya tergolong tidak mandiri $(71 \%)$

5. Ada hubungan yang tidak signifikan antara status gizi dengan kemandirian lansia baik kelompok usia $<75$ tahun dan kelompok usia $\geq 75$ tahun dengan nilai signifikan masing-masing $\mathrm{p}=0,619$ dan $\mathrm{p}=0,191$

6. Ada hubungan yang tidak signifikan antara penyakit hipertensi dengan kemandirian lansia baik kelompok usia $<75$ tahun dan kelompok usia $\geq 75$ tahun dengan nilai signifikan masingmasing $p=0,447$ dan $p=0,362$.

\section{SARAN}

Sebaiknya pada saat kegiatan posyandu lansia sebagai sarana untuk memantau status gizi dan status kesehatan serta ketaan diet para lansia penderita hipertensi 
hendaknya senantiasa diberikan penyuluhan dan atau konsultasi gizi untuk meningkatkan pemahaman tentang diet yang sedang dijalani serta sebagai sarana dalam meningkatkan kemandirian lansia, khususnya untuk kelompok usia $\geq 75$ tahun sehingga para lansia merasa diberdayakan. Dilaksanakan peningkatan pengetahuan dan keterampilan kader posyandu dalam hal tatalaksana diet hipertensi, sehingga dapat memberikan edukasi yang sesuai pada anggota kelompok posyandu lansia yang menderita hipertensi.

\section{DAFTAR PUSTAKA}

Abdelrahman HMM, Elawam AEE. (2012). Nutrition Status in Community Dwelling Older Population in An Egyptian Urban Area. The J of Aging Research \& Clinical Practice Online. www.jarcp.com.(diakses, 16 Januari 2019).

Adriani dan Wirjatmadi. (2012). Peranan Gizi dalam Siklus Kehidupan. Jakarta: Kencana Prenada Media Group.

Alfyanita A, Martini RD, Kadri. (2016). Hubungan Tingkat Kemandirian dalam Melakukan Aktivitas Kehidupan Sehari-Hari dan Status Gizi pada Usia Lanjut di Panti Sosial Tresna Werdha Sabai Nan Aluih Sicincin. Jurnal Kesehatan Andalas. 6(1):201-208. http://jurnal.fk.unand.ac.id. (diakses, 16 Januari 2019).

Almatsier, dkk. (2011). Gizi Seimbang dalam Daur Kehidupan. Jakarta: Gramedia Pustaka Utama.

Arisman, MB. (2009). Gizi dalam Daur Kehidupan. Jakarta: Penerbit Buku Kedokteran.

Astuti FA. (2012). Hubungan Status Gizi dengan Kualitas Hidup Geriatri di Posyandu Lansia Ngudi Sehat Bibis Baru Nusukan Banjarsari Surakarta. Naskah Publikasi. http://eprints.ums.ac.id. (diakses, 24 September 2017).
Atut Andica. (2013). Gambaran Tingkat Kemandirian Landia Di Dusun Blimbing Desa Sukorejo Kecamatan Sukorejo Kabupaten Ponorogo. KTI, Universitas Muhammadiyah Ponorogo. http://eprints.umpo.ac.id. (diakses 29 November 2017).

Aulia QA. (2016). Hubungan Tingkat Kemandirian Activity of Daily Living (ADL) Lansia dengan Kualitas Hidup pada Lansia di Wilayah Kerja Puskesmas Lubuk Buaya Kelurahan Tabing Padang Tahun 2016. Skripsi. http://scholar.unand.ac.id. (diakses, 24 September 2017).

Badan Pusat Statistik. (2015). Statistik Penduduk Lanjut Usia. https://www.bps.go.id. (diakses, 21 Januari 2019).

Badan Pusat Statistik. (2016). Statistik Penduduk Lanjut Usia. https://www.bps.go.id. (diakses, 27 September 2017).

Direktorat Bina Gizi dan Kesehatan Ibu dan Anak. (2012). Pedoman Pelayanan Gizi Lanjut Usia. perpustakaan.depkes.go.id. (diakses, 27 September 2017).

Ediawati, Eka. (2013). Gambaran Tingkat Kemandirian Dalam Activity of Daily Living (ADL) Dan Resiko Jatuh Pada Lansia di Panti Sosial Tresna Wredha Budi Mulia 01 dan 03 Jakarta Timur. Skripsi. Universitas Indonesia. http://lib.ui.ac.id/. (diakses 29 November 2017).

Fajar. (2016). Kemandirian, Stress dan Konsumsi Pangan Kaitannya dengan Status Gizi dan Status Kesehatan Lansia di Wilayah UPT Puskesmas Dramaga, Bogor. http://repository.ipb.ac.id. (diakses, 24 September 2016).

Fatmah. (2010). Gizi Usia Lanjut. Jakarta: Penerbit Erlangga.

Hidayaty DF. (2012). Hubungan Aktivitas Fisik dan Aktivitas Kognitif terhadap Kejadian Demensia pada Lansia di 
Kelurahan Sukabumi Selatan Tahun 2012. http://repository.uinjkt.ac.id. (diakses, 29 November 2017).

Husain Salindra. (2013). Hubungan Dukungan Keluarga dengan Kemandirian Lansia dalam Pemenuhan Aktivitas Sehari-Hari di Desa Tualango Kecamatan Tilango Kabupaten Gorontalo. Skripsi. Universitas Negeri Gorontalo. http://kim.ung.ac.id. (diakses, 29 November 2017).

Jerome GJ, Glass TA, Mielke M, Xue Q, Anderson RE, Fried LP. (2006). Physical Activity Participation by Presence and The Women's Health and Aging Studies. Journal Of Gerontol, Vol. 61A, No.11, 1171$1176 . \quad$ https://academic.oup.com. (diakses, 16 Januari 2019).

Kaur H, Kaur H, Venkateashan M. (2015). Factor Determining Family Support and Quality of Life of Elderly Population. Journal Medical Science and Public Health: 4(8). https://www.ejmanager.com. (diakses, 17 Januari 2019).

Norhasanah. (2015). Analisis FaktorFaktor yang Mempengaruhi Status Gizi dan Kesehatan Lansia Perempuan pada Panti Sosial dan Lembaga Sosial Masyarakat di Banjarmasin. Skripsi. Institut Pertanian Bogor. http://repository.ipb.ac.id. (diakses, 24 September 2017).

Nurhalimah FR. (2016). Hubungan Status Kesehatan, Aktivitas Fisik, dan Dukungan Sosial dengan Kemandirian Lansia di Desa Ciniru, Kecamatan Ciniru, Kabupaten Kuningan. Skripsi. Institut Pertanian Bogor. http://repository.ipb.ac.id. (diakses, 24 September 2017).

Pandiri KE. (2009). Gambaran Pengetahuan Gizi dan Pola Makan Penderita Hipertensi pada Pasien Rawat Jalan di Rumah Sakit Dr.
Wahidin Sudirohusodo Makassar. Karya Tulis Ilmiah. Program Studi Diploma III Jurusan Gizi Poltekkes Kemenkes Makassar.

Paul C, Riberio O, Teixeira L. (2012). Ative Ageing: An Empirical Approach to The WHO Model. Journal Gerontol Biol Sci Med Sci, ID: 382972, doi:10.1155/2012/382972.https://www .ncbi.nlm.nih.gov/pubmed/23193396( diakses, 16 Januari 2019).

Pusat Data dan Informasi Kemenkes RI. (2013). Gambaran Kesehatan Lanjut Usia diIndonesia. www.depkes.go.id. (diakses, 27 September 2017).

Pusat Data dan Informasi Kemenkes RI. (2015). Hipertensi di Indonesia. www.depkes.go.id. (diakses, 27 September 2017).

Pusat Data dan Informasi Kemenkes RI. (2016). Situasi Lanjut Usia (Lansia) di Indonesia. www.depkes.go.id. (diakses, 27 September 2017).

Rinajumita. (2011). Faktor-Faktor yang Berhubungan dengan Kemandirian Lansia di Wilayah Kerja Puskesmas Lampasi Kecamatan Payakumbuah Utara. Program Studi Ilmu Kesehatan Masyarakat.

http://repository.unand.ac.id. (diakses, 15 Januari 2019).

Rohaedi, Putri ST dan Karimah AD. (2016). Tingkat Kemandirian Lansia dalam Activities Daily Living di Panti Sosial Tresna Werdha Senja Rawi. Jurnal Pendidikan Keperawatan Indonesia Vol.2 No. 1 Juli 2016.

Sirait FRH. (2015). Hubungan Status Gizi dan Penyakit Hipertensi dengan Tingkat Kemandirian Lansia di Posyandu Lansia Puskesmas Kedaton. Skripsi. Fakultas 